\title{
Terrestrial Slugs in Neotropical Agroecosystems
}

\author{
Mariangie Ramos ${ }^{1 *}$, Suzete Rodrigues Gomes ${ }^{2}$, Yashira Gutierrez ${ }^{1}$, \\ Olgaly Ramos-Rodriguez ${ }^{1}$ and Mariella Carmadelli Uzeda ${ }^{3}$
}

${ }^{1}$ Department of Agricultural Technology, University of Puerto Rico, Utuado, PR, United States, ${ }^{2}$ Laboratório de Malacologia, Instituto Oswaldo Cruz, FIOCRUZ, Rio de Janeiro, Brazil, ${ }^{3}$ Centro Nacional de Pesquisa de Agrobiologia, Empresa Brasileira de Pesquisa Agropecuaria, Rio de Janeiro, Brazil

Slugs can be important agricultural pests in tropical regions. They are also intermediate hosts of parasitic nematodes, such as Angiostrongylus costaricensis and A. cantonensis, which can cause abdominal and cerebral angiostrongyliasis in humans. Management of slugs in conventional agriculture has relied heavily in the use of pellets containing metaldehyde. In this article, we review cases of slug problems and their management in neotropical agroecosystems.

Keywords: terrestrial mollusks, pest management, organic agriculture, tropics, farmer knowledge, global change, Latin America

\section{OPEN ACCESS}

Edited by:

Helda Morales,

The South Border College

(ECOSUR), Mexico

Reviewed by:

Heidi Liere,

Seattle University, United States

Amarendra Narayan Misra,

Central University of Jharkhand, India

${ }^{*}$ Correspondence:

Mariangie Ramos

mariangie.ramos@upr.edu

Specialty section:

This article was submitted to Agroecology and Ecosystem Services, a section of the journal

Frontiers in Sustainable Food Systems

Received: 20 January 2021 Accepted: 29 April 2021

Published: 16 July 2021

Citation:

Ramos M, Gomes SR, Gutierrez Y, Ramos-Rodriguez $O$ and Uzeda MC (2021) Terrestrial Slugs in Neotropical Agroecosystems.

Front. Sustain. Food Syst. 5:656492.

doi: 10.3389/fsufs.2021.656492

\section{INTRODUCTION}

Terrestrial gastropods (land snails, semi-slugs and slugs) are a very diverse group, with $\sim 24,000$ described species and 11,000-40,000 undescribed species worldwide (Lydeard et al., 2004). Several species of terrestrial gastropods are considered pests, however this fraction is small compared to the diversity of terrestrial Gastropoda (Neubert et al., 2019). Terrestrial gastropods contribute to litter decomposition (Meyer et al., 2013), and may even have roles in plant disease control in agroecosystems (Hajian-Forooshani et al., 2020).

Among the terrestrial gastropods, slugs have been identified as one of the most successful pest groups (South, 2012), especially in crops that require high physical disturbance (Port and Ester, 2002). For example, the Iberian slug Arion vulgaris (Moquin-Tandon, 1855) is a serious pest of vegetables and arable crops in Europe (Kozlowski et al., 2018; CABI, 2020), and is considered one of the top invasive species by the European Network on Invasive Alien Species (Slotsbo, 2014). In the US Midwest, slugs are one of the main pest problems for no-till growers (Douglas and Tooker, 2012).

Terrestrial slugs are not a monophyletic group, but a case of convergent evolution in which the slug form evolved from different lineages of land snails that gradually lost their shell, through a process called limacization (Simone, 2018). The slug body form is present in the Stylommatophora (land snails and slugs) and Systellommatophora (aquatic and terrestrial slugs) clades of the Eupulmonata (Schrodl, 2014). Thomé and Gomes (2011) cited 13 families of slugs in Brazil, of which only two of them are native to the Americas: Veronicellidae (common in tropical areas around the word) and Philomycidae (native from Asia and Northern America). Thomé (1993) reviewed the native Veronicellidae in the Americas, mentioning 144 species names classified in 18 genera.

Limacization resulted in adaptive radiation in land snail lineages, as slugs became adapted to diverse moist and protected spaces, such as crevices in rocks and wood debris (Hausdorf, 2001). The loss of the shell also allowed for more movement and less calcium dependence, making slugs more successful as pests (South, 2012). For example, in Venezuela, farmers do not consider snails pests but consider that slugs are a significant pest problem (Perichi, 2014). 
Slugs in neotropical agroecosystems have been poorly documented in the literature. An exception to this, was the study of the bean slug, Sarasinula plebeia (Fischer, 1868), infestations in Central America in the 1980's. It was estimated that more than 400,000 farmers suffered economic losses due to this slug (Andrews, 1987a). Veronicellid slugs are also considered the main intermediate hosts of Angiostrongylus costaricensis (Morera and Céspedes, 1971), and can be naturally infected with A. cantonensis (Chen, 1935), which can cause abdominal and cerebral angiostrongyliasis in humans, respectively (Valente et al., 2020).

In this mini-review, we explore slug problems and management in the Neotropics. We review the literature: (1) to describe examples of slug infestations in the Neotropics and their potential causes; and (2) to explore preventive management strategies that have been used for slugs in this region. We expand on the review by Rueda et al. (2002), by including slug experiences from South America and the Caribbean.

\section{METHODS}

We conducted a literature review using the following search terms in the topics category: slugs AND pest AND management. We used Web of Science All Databases, which include: WOS, BCI, CABI, KJD, MEDLINE, RSCI, SCIELO, ZOOREC. We search for all available years (1864- February 2020). A total of 1,320 records were obtained in 89 research categories. We refined research results to limit results to "Agriculture" research area, resulting in 866 records. Most records are from Europe (526 records) and North America (114 records). South America (16 records) and Africa (13 records) are the continents with the least number of records. In order to find more articles from the Neotropics, we conducted additional searches using the terms "babosas" (71 records), "lesmas" (13 records), and "limaces" (99 records). In addition, we used the term "babosas" and "lesmas" in Google search engine to find information in local management guides, thesis, or technical reports.

\section{SLUGS AS PESTS IN THE NEOTROPICS}

The first reports of crop damage by slugs in the Neotropics are from Jamaica, where slugs were observed attacking coffee (Cockerell, 1893a) and strawberries (Cockerell, 1893b). In Trinidad, slugs caused significant damage to sweet potato plantations early in the 20th century (Callan, 1941). Pereira and Gonçalves (1949) later described slugs that affected bananas and vegetables in the coast of São Paulo state, Brazil. After a hiatus in publications, more articles about slugs in the Neotropics were published in the 1980's. Since the late 1960's, the bean slug $S$. plebeia started to cause severe damage to beans, a staple food, in Central America (Rueda et al., 2002). The Integrated Pest Management Project of Zamorano University (with financial support from USAID) conducted many studies to find suitable management practices to control S. plebeia. Sarasinula plebeia is believed to be native to the Americas despite its widespread distribution throughout tropical regions (Daglio et al., 2020).
Andrews and Dundee (1987) studied the historic reports of the species and concluded that it was accidentally introduced to El Salvador, from where it spread throughout Central America, causing havoc to Central American farmers. In South America, $S$. plebeia is also known to cause damage to bean crops (Sannazzaro et al., 2000), but it is not considered a major pest (Cardona, 1994). Currently, S. plebeia is present in Central America, but farmers do not consider it a pest as important as whiteflies or leafhoppers in beans (R. Trabanino personal communication).

In the 1990's, the concern for slug damage intensified in Colombia, when higher than average rainfall was recorded, and significant coffee losses were experienced (Posada-Flórez et al., 2001). Slugs are considered pests in vegetable (Santacruz et al., 2011), flower and coffee production of Colombia. Martinez et al. (1994) first mentioned that slugs were problematic for flower production in Colombia, as they fed on the new shoots of plants and reduced flower production. Slugs are also problematic in flower production and many slugs are considered quarantine pests in importing countries (Robinson, 1999). Hausdorf (2002) identified Deroceras invadens (Reise et al., 2011), Deroceras panormitanum (Lessona and Pollonera, 1882), Deroceras reticulatum (Müller, 1774), and Lehmannia valentiana (Férussac, 1821) as serious pests in flowers of Colombia. The slug Colosius confusus (Gomes et al., 2013), a newly described species, was frequently intercepted by US authorities in fresh flowers coming from Colombia and Ecuador (Gomes et al., 2013). C. confusus also feeds and can be problematic on coffee plantations in Colombia and Peru (Constantino et al., 2010; Gomes et al., 2013). After 2000, researcher groups were formed to study the systematics, biology and management of terrestrial mollusks in Colombia (Moreno Suárez et al., 2008). Currently, slugs continue to be a problem in Colombian floriculture (mainly for Alstroemeria, Dianthus and Hydrangea), but are not perceived as major pests (A. Paez personal communication).

In recent years, slug species have been reported to cause damage in several crops in the Neotropics, including vanilla (Velazquez-Montes de Oca et al., 2014), passion fruit (de Oliveira and Frizzas, 2014), strawberry (Landal et al., 2019; Castellanos Gonzalez et al., 2020), and grapes (Baronio et al., 2014; Rodriguez et al., 2019). Latipes erinaceus (Colosi, 1921) and Sarasinula linguaefomis (Semper, 1885) are other species that are becoming problematic in the Neotropics. They are currently, one of the main pests of large-scale soy production in Brazil. Observations of $L$. erinaceus in the lab, have shown that it has a higher reproductive capacity than other species of the Veronicellidae family, spawning every month (S. R. Gomes unpublished).

From a food safety standpoint, the presence of slugs in leafy greens and fresh fruit production in the Neotropics is of particular concern. Slugs eat and leave secretions in leaves and fruits. Terrestrial mollusks, including slugs, are vectors of the parasite A. costaricensis and A. cantonensis. These parasites can survive in produce that is consumed raw (Kramer et al., 1998). In Santa Catarina, Brazil, A. costaricensis infection of $86 \%$ was observed in S. linguaeformis (Laitano et al., 2001). S. linguaefomis can be a pest of corn, beans, soybeans and leafy greens (Grisotti and Ávila-Pires, 2011; Moura et al., 2018). This slug is considered native to Brazil and it is widespread throughout the neotropical 
region (Valente et al., 2020). It usually occurs in low numbers in Rio de Janeiro State (Oliveira et al., 2015). However, in 2015, we studied an outbreak of this species in small scale vegetable farms of the Cachoeiras de Macacu Municipality (unpublished). In 2020, this species was also found in Puerto Rico, affecting small-scale agroecological vegetable production. Recently, the exotic Chinese slug Meghimatium pictum (Stoliczka, 1873) was associated to a case of abdominal angiostrongyliasis in a region where it is a grape pest (Rodriguez et al., 2019). This brings attention to the possible risk of human infection associated with accidental ingestion of contaminated fruit or vegetables containing larvae of the parasitic nematode A. costaricensis, the etiological agent of this parasitosis.

\section{SLUG MANAGEMENT IN THE NEOTROPICS}

After examining abstracts and articles, we found 389 records that covered the topic of slug management. In general, seventyfive records (19\% of records) covered metaldehyde use, and 55 covered other organic (i.e., with carbon) pesticides such as methiocarb. Records about metaldehyde use start in 1940 (with Gimingham, 1940), while records about organic pesticides start in the 1960's (with Henderson, 1968). Twenty-six records were about the use of inorganic compounds for slug management, which was the oldest slug management practice described in the literature (Baltet, 1889). Two studies in the Neotropics mentioned the use of lime for semi-slug and slug management (Bastos Garcia et al., 2012; Capinera, 2018). Literature about biological control of slugs is dominated by studies about carabid beetles ( 25 records) and nematodes (45 records). These records begin in the 1980's for carabids (Symondson, 1989), and early 1990's for nematodes (Wilson et al., 1994). Other slug management practices include the use of botanical extracts, traps, solutions of conspecifics, Bacillus thuringiensis, and barriers. Also, there were records that examined the effect of different farm management practices on slugs, such as tilling, use of cover crops, irrigation regimes and crop rotation. Most slug management records are from temperate areas and were recently reviewed by Le Gall and Tooker (2017).

The management of slugs (and snails) in conventional agricultural areas has relied heavily on the use of metaldehyde pellets. The use of metaldehyde $\left(\mathrm{C}_{8} \mathrm{H}_{16} \mathrm{O}_{4}\right)$ as a molluscicide began in the 1930's, after the discovery of its molluscicide properties by women gardeners in South Africa (Gimingham, 1940). In the Caribbean, it started to be used in 1937 (Callan, 1941). In South America, it has been known to be used since the 1940's (Pereira and Gonçalves, 1949). Slugs died 1-2 days after consuming metaldehyde pellets, but the adequate consumption of pellets does not always occur, making the method inefficient (Bailey, 2002). Metaldehyde is soluble in water, highly mobile in soils and generally stable to abiotic degradation (EPA, 2006). In Europe, it has been identified as a water pollutant, being frequently detected in surface waters above the EU Drinking Water Directive (Kay and Grayson, 2014). Metaldehyde was banned in 2018 in England because of its pollutant potential, however the ban was later overturned. Metaldehyde is commonly used by farmers in the Neotropics. Five (out of 11) management articles in the Neotropics examined the used of metaldehyde to manage slugs. Metaldehyde residue limits exists for the export of some products, such as legume foliage (EPA, 2015).

Pellets containing iron phosphate have been used since the 1990's as an alternative to metaldehyde pellets in some countries (EPA, 1998). Iron phosphate pellets can be an effective curative slug control method (Speiser and Kistler, 2002). Also, iron phosphate is non-harmful to humans or the environment (EPA, 1998) and can be used in organic agriculture (USDANOP). Recently, pellets containing ferric sodium EDTA have also become commercially available in some countries as another curative slug control method (Capinera and Rodrigues, 2015). Ferric sodium EDTA also has very low toxicity to humans and the environment (EPA, 2008). In the Neotropics, iron phosphate is commercially available but can be less accessible than metaldehyde molluscicides (slightly higher cost per gram and lower distribution to rural areas). Laboratory experiments in Brazil and Florida, showed that iron phosphate pellets can be more effective or slightly less effective than metaldehyde pellets, respectively (Baronio et al., 2014; Capinera and Rodrigues, 2015).

Several management practices were followed by farmers to manage S. plebeia in Central America. Beans are a staple food of family farmers in Central America, and are usually planted in a relay system with maize. Some of the management practices first implemented by Honduran farmers to deal with the new slug problem were: planting in slopes, burning maize residues before bean planting, deep tilling, and empirical pesticide use (Andrews, 1987a). From 1975 to 1987, the Honduran government subsidized the purchase of metaldehyde to distribute among farmers. Andrews (1985) argued that this subsidy resulted in less effective chemical control than that of Mexico or El Salvador, where private chemical companies lead control efforts. Several slug management techniques were evaluated at Zamorano, Honduras with farmer participation (Rueda et al., 2002). Some Honduran farmers preferred to combine different management techniques, including weed management, weed traps, night killing of slugs with a stake, and use of homemade baits (with Jatropha curcas seeds or metaldehyde) when there are more than 5 slugs per ten plants (FAO, 2005). Farmers using traditional "frijol tapado" systems in Costa Rica preferably use east-facing slopes and eliminate some of the plant species that favor slugs (Meléndez, 2004).

Agroecosystems in the Neotropics can range from smallscale highly diverse home gardens to large-scale conventional monocultures of crops such as sugar cane, soy, banana or palm oil. Family farming and agroforestry systems are also important in the region (Peters et al., 2016; Schneider, 2016), and can contribute to the conservation of biodiversity in these landscapes (e.g., Rooduijn et al., 2018). A comparison of slug abundance and plant damage in two agroecological and conventional farms in Colombia, showed that although slugs were more abundant in the agroecological farm, only one variety of lettuce had more damage in this system (Cordoba Vargas and Leon Sicard, 2010). 
Agroforestry systems and landscapes with natural vegetation can benefit from higher predation of herbivores that feed on crops (Maas et al., 2020). Natural enemies of slugs include birds, reptiles, mammals, planarians, nematodes, insects, and mites, among others (Baker, 2004). In other regions, there has been an emphasis on the study of carabids and nematodes for slug biological control. In the Neotropics, natural enemies of slugs have not been studied in detail, but there are some documented and anecdotal examples. Firefly (Coleoptera: Lampyridae) larvae are known to feed on slugs (Viviani, 2001), but the rate of predation has been low under laboratory conditions (1 slug every 5 days; Rueda et al., 2002). Native planarians preferentially feed on introduced slugs and snails (Boll and Leal-Zanchet, 2015). Toads were used successfully in gardens of Colombia to reduce slug populations (Posada-Flórez et al., 2001). Since the Neotropics are very diverse, many natural enemies of slugs may remain to be discovered. For example, five new species of snakes that feed on terrestrial mollusks were recently discovered in Ecuador and Peru (Arteaga et al., 2018).

Nematodes and pathogens of slugs are also of interest for slug biological control efforts worldwide. The nematode Phasmarhabditis hermaphrodita (Schneider, 2016) is available commercially in Europe (Pieterse et al., 2016), and has been recently introduced to several countries (Howe et al., 2020). In the Neotropics, Mermithid and Rhabditid nematodes have been found parasitizing slugs (Thiengo, 1995; Posada-Flórez et al., 2001; Rueda et al., 2002; Moreno Suárez et al., 2008). In Brazil, we found Rhabditid nematodes parasitizing few slugs. Pathogenic bacteria and fungi can also infect slugs (Moreno Suárez et al., 2008; Galvis and Moreno, 2018).

\section{OTHER CONSIDERATIONS}

\section{Global Change and Slugs in Agricultural Areas}

The global distribution of terrestrial gastropods is changing. Humans have facilitated the dispersal of gastropod species across the globe, breaking geographic barriers and homogenizing global terrestrial gastropod diversity (Capinha et al., 2015). In this process, many species have become endangered, sometimes because of other mollusk pest biological control efforts (Lydeard et al., 2004). Other terrestrial gastropod species have benefited from human-facilitated dispersal, and have become invasive pests (Cowie et al., 2008). This was observed early on by Binnei (1871), when he described "All the species mentioned below are of foreign origin. They were imported from England. They are found only in close proximity to man. They have also been imported into other colonies of England, and probably are destined to become the most cosmopolitan of mollusks." There are at least 13 alien species of slugs in South America (Rumi et al., 2010; Gregoric et al., 2013). In Colombia, at least seven European slug species have been introduced in the highlands, some more than a century ago (Hausdorf, 2002).

Introduced non-native slug species can have detrimental effects in agricultural areas. This is the case of slugs such as Deroceras reticulatum in Australia (Nash et al., 2007), and the
Cuban slug Veronicella cubensis (Pfeiffer, 1840) in the island of Rota (Robinson and Fields, 2010). We discussed examples in this article showing that this can also be the case in the Neotropics. Early on, Cockerell (1893b) described the introduction of European slugs in strawberries in Jamaica, stating that "They and their eggs come in the earth about the roots, and, in many cases, it must be practically impossible to detect them on arrival." In the case of the bean slug, the species was accidentally introduced from South America and caused damage to both conventional and diverse small-scale farmers in Central America (Andrews and Dundee, 1987). In the island of Puerto Rico, the non-natives $V$. cubensis and S. linguaefomis are causing problems to smallscale vegetable farmers. Introduced slug species are expected to thrive more in disturbed habitats, such as agricultural lands, than native slug species (Ryser et al., 2011). However, they can colonize natural areas and affect native plant communities (Shiels et al., 2014).

The range of invasive slugs may increase with climate change, since some species are favored by warmer conditions (Sommer and Cowie, 2020). Although terrestrial gastropods are susceptible to desiccation, they can also have costly behavioral and physiological mechanisms that help them cope with high temperature and drought periods (Nicolai and Ansart, 2017). Temperature increases, changes in rainfall patterns and increase of extreme weather events are expected for the Neotropics in the next 100 years. Traditionally, farmers associate periods of rains with higher slug abundance. Extreme rain events, such as hurricanes, decreased the abundance of the native semi-slug Gaeotis nigrolineata (Shuttleworth, 1854) in Puerto Rico (Willig and Camilo, 1991).

\section{Slug Identification and Monitoring}

Slug diversity in agroecosystems in the Neotropics should be studied and considered more. This could be a first step to detect potential new slug invaders, and to better understand the drivers of sudden slug infestations in farms. A caveat to this is that slug identification can be difficult. A combination of external characters and internal anatomy is usually required to correctly identify species. Robinson (1999) presents the example of the process from the USDA Plant Protection and Quarantine Program, in which: (1) port inspectors find mollusks in arriving shipments; (2) port identifiers (PI) try to identify the species; (3) if the PI cannot identify the species, the PI dissects the individual and takes digital images of it; (4) the images are rapidly sent to the National Malacology Laboratory for identification; (5) if needed, the individual is sent for molecular analysis.

Recently, a new network of malacologists was created to track the presence of non-native mollusks in South America (Darrigran et al., 2020). The group is an important first step to increase awareness about this topic in our region. More attention should also be given to train extension and other agriculture professionals in slug identification, and to improve the identification (e.g., molecular) tools of slugs in the Neotropics. Participatory strategies may also help in the detection of new slug invaders or infestations. Knowledge dialogues or exchanges with and between farmers are an important agroecological practice in Latin America (Mier y Terán Giménez 
Cacho et al., 2018). In the case of the bean slug in Honduras, farmers would prefer using "trash" traps (i.e., pilled plants residues from weeding and pruning) to monitor slug presence than other traps that required materials from outside the farm (Andrews, 1987b). Relying on damage observation was not recommended, as slug populations were difficult to manage at that point. In other regions, citizen science has been used to detect the occurrence of invasive slugs in private and public lands (Dorler et al., 2018; Morii et al., 2018). The participation of malacologists in social media groups, such as Facebook Groups "Moluscos del Ecuador" or "Biodiversidad de Puerto Rico," can make slug identification more accessible to the general public.

We found few initiatives that were testing unmanned vehicles for slug detection in farms. In Colombia, drones were experimentally used to determine the presence of slugs in flower cultivation (Caceres Florez et al., 2015). The drones detected leave damage, not slug individuals. Because slugs are frequently hidden in the soil, land unmanned vehicles have also been considered in other regions (Godeke et al., 2019).

\section{CONCLUSIONS}

Slugs can be important pests in agricultural areas worldwide. In the Neotropics, reported examples of slug pests are fewer than in other regions such as Western Europe. Many factors could be hypothesized to explain this, starting with less abundance of malacologists studying terrestrial gastropods in the region. Also, the ecosystem service of natural pest regulation could be preventing slug populations to reach economic injury levels. Another possibility is that slugs are not considered pests by farmers, as observed for insect herbivores in traditional milpa systems of Guatemala (Morales and Perfecto, 2000). Alternatively, management of slugs is not studied extensively in the Neotropics because metaldehyde has been used to kill outbreaks of terrestrial mollusks for nearly 80 years. The examples presented in this article show that there are instances when slugs have been problematic in the Neotropics. It is important to understand these and other examples in order to prevent future slug pest problems in farms of our region.

Slugs and their management have been understudied in the Neotropics. More research is needed about their diversity

\section{REFERENCES}

Andrews, K. L. (1985). Control químico de babosas especialmente la babosa del frijol. Ceiba 26, 90-102.

Andrews, K. L. (1987a). La importancia de las babosas veronicélidos en Centroamérica. Ceiba 28, 149-153.

Andrews, K. L. (1987b). Técnicas de muestreo para la determinación de la densidad poblacional y actividad de las babosas veronicélidos. Ceiba 28, 209-228.

Andrews, K. L., and Dundee, D. S. (1987). Las babosas veronicéllidos de Centroamérica con énfasis en Sarasinula plebeia (= Vaginulus plebeius). Ceiba 28, 163-172.

Arteaga, A., Salazar-Valenzuela, D., Mebert, K., Peñafiel, N., Aguiar, G., and Sànchez-Nivicela, J. C., et al. (2018). Systematics of South American snail-eating snakes (Serpentes, Dipsadini), with the description and biology in our region. Weather extremes and international trade are expected with global change, and invasive slugs could benefit from these changes. Farmers already use a variety of techniques including barriers, traps and resistant crops, and socialize this information among themselves. However, these preventive management practices have not been sufficiently documented or validated in the scientific literature. The case of the bean slug provided important information about slug management in our region. However, these studies were conducted almost 40 years ago. New social and ecological technologies may exist to advance slug management in the Neotropics.

\section{DATA AVAILABILITY STATEMENT}

The raw data supporting the conclusions of this article will be made available by the authors, without undue reservation.

\section{AUTHOR CONTRIBUTIONS}

OR-R and MR conducted the systematic literature review. SG contributed additional literature, slug infestation cases, and expertise on slug taxonomy and biology. All authors contributed to the writing of the manuscript, with MR and SG contributing the most.

\section{FUNDING}

This work was supported by the USDA-NIFA AFRI Small and Medium Sized Farms Program (Award \#2019-6900629335), a Fulbright Scholarship (MR) and Embrapa's Agrofuturo Program (MU).

\section{ACKNOWLEDGMENTS}

We thank R. Trabanino and A. Paez for their communications. Two reviewers provided-important feedback to improve the article. As part of this article was written during the COVID-19 pandemic, we would like to thank our families and editors for their support in the writing process. of five new species from Ecuador and Peru. ZooKeys 766, 79-147. doi: $10.3897 /$ zookeys.766.24523

Bailey, S. E. R. (2002). "Chapter 2: molluscicidal baits for control of terrestrial gastropods," in Molluscs as Crop Pests, 1st Edn., ed G. M. Barker (New York, NY: CABI Publishing).

Baker, G. M. (2004). Natural Enemies of Terrestrial Molluscs, 1st Edn. Cambridge, MA: CABI Publishing.

Baltet, M. (1889). Le sulfate de cuivre contre les limaces et les escargots. Bull. Soc. Linn. Brux. 15, 99-100.

Baronio, C. A., Botton, M., Gomes, S. R., and Robinson, D. G. (2014). First record of qualitative losses caused by Meghimatium pictum in vineyards of Southern Brazil and the effects of two molluscicides for its control. Ciencia Rural 44, 1715-1720. doi: 10.1590/0103-8478cr20130522

Bastos Garcia, M. V., Arruda, J. O., Pimpao, D. M., and Garcia, T. B. (2012). Occurrence and control of Omalonyx slugs (Gastropoda, Succineidae), pests 
of the elephant-grass Pennisetum purpureum (Poaceae) in Rio Preto da Eva, Amazonas. Acta Amaz. 42, 227-230. doi: 10.1590/S0044-59672012000200007

Binnei, W. G. (1871). The mollusks of our cellars. Am. Nat. 4, 166-171. doi: $10.1086 / 270553$

Boll, P. K., and Leal-Zanchet, A. M. (2015). Predation on invasive land gastropods by a Neotropical land planarian. J. Nat. Hist. 49, 983-994. doi: $10.1080 / 00222933.2014 .981312$

CABI (2020). Arion vulgaris (Spanish slug) Datasheet. Available online at: https://www.cabi.org/isc/datasheet/6963\#tosummaryOfInvasiveness (accessed January 11, 2021).

Caceres Florez, C. A., Hurtado, D. A., and Ramos Sandoval, O. L. (2015). Methodology for pest damage recognition in Begonia semperflorens (sugar flower) crop through image processing. Acta Agronomica 64, 273-279. doi: 10.15446/acag.v64n3.42657

Callan, E. M. C. (1941). The control of slugs by meta bait in Trinidad, B.W.I. J. Trop. Agric. 18, 211-213.

Capinera, J. L. (2018). Assessment of barrier materials to protect plants from Florida leatherleaf slug (Mollusca: Gastropoda: Veronicellidae). Fla. Entomol. 101, 373-381. doi: 10.1653/024.101.0327

Capinera, J. L., and Rodrigues, C. G. (2015). Biology and control of the leatherleaf slug Leidyula floridana (Mollusca: Gastropoda: Veronicellidae). Fla. Entomol. 98, 243-253. doi: 10.1653/024.098.0141

Capinha, C., Essl, F., Seebens, H., Moser, D., and Pereira, H. M. (2015). The dispersal of alien species redefines biogeography in the Anthropocene. Science 348, 1248-1251. doi: 10.1126/science.aaa8913

Cardona, C. (1994). "Chapter 22: Insectos y otras plagas invertebradas en frijol en America Latina," in Problemas de Producción del Frijol en los Trópicos, 2nd Edn., eds M. Pastor-Corrales and H. F. Schwartz (Cali, CO: CIAT).

Castellanos Gonzalez, L., Cespedes Novoa, N., and Baldovino Sanjuan, A. (2020). Organic alternatives for the achievement of cleaner strawberry production in Pamplona, North of Santander. INGE CUC 16, 187-196. doi: 10.17981/ingecuc.16.1.2020.14

Cockerell, T. D. A. (1893a). Slugs injuring coffee. Nautilus 6, 127-128.

Cockerell, T. D. A. (1893b). The small grey Slug Agriolimax agrestis in Jamaica. Nautilus 7, 21-22.

Constantino, L. M., Gomes, S., and Benavides, P. (2010). Descripción y daños causados por las babosas Colosius pulcher y Sarasinula plebeia en el cultivo de café en Colombia. Avances Técnicos CENICAFE 392, 1-8.

Cordoba Vargas, C. A., and Leon Sicard, T. (2010). Efecto del manejo agroecológico y convencional sobre la fluctuación de babosa en cultivos de lechuga en Tenjo, Cundinamarca (Colombia). Acta biol. Colomb. 15, 115-128.

Cowie, R. H., Hayes, K. A., Tran, C. T., and Meyer, W. M. (2008). The horticultural industry as a vector of alien snails and slugs: widespread invasions in Hawaii. Int. J. Pest Manag. 54, 267-276. doi: 10.1080/09670870802403986

Daglio, E. D., Lucía, M., de, Gomes, S. R., and Gregoric, D. E. G. (2020). First records of the bean-slug Sarasinula plebeia (Gastropoda: Veronicellidae) in Argentina. Pap. Avulsos Zool. 60:e20206047. doi: 10.11606/1807-0205/2020.60.47

Darrigran, G., Agudo-Padron, I., Baez, P., Belz, C., Cardoso, F., Carranza, A., et al. (2020). Non-native mollusks throughout South America: emergent patterns in an understudied continent. Biol. Invasions 22, 853-871. doi: 10.1007/s10530-019-02178-4

de Oliveira, C. M., and Frizzas, M. R. (2014). Principais pragas do maracujazeiro amarelo (Passiflora edulis $f$. flavicarpa Degener) e seu manejo. Planaltina: Embrapa Cerrados.

Dorler, D., Kropf, M., Laaha, G., and Zaller, J. G. (2018). Occurrence of the invasive Spanish slug in gardens: can a citizen science approach help deciphering underlying factors? BMC Ecol. 18:23. doi: 10.1186/s12898-018-0179-7

Douglas, M. R., and Tooker, J. F. (2012). Slug (Mollusca: Agriolimacidae, Arionidae) ecology and management in no-till field crops, with an emphasis on the mid-Atlantic Region. J. Integr. Pest Manag. 3, C1-9. doi: 10.1603/IPM11023

EPA (1998). Iron (Ferric) Phosphate (034903) Technical Document. Washington, DC: EPA.

EPA (2006). Reregistration Eligibility Decision for Metaldehyde. Washington, DC: EPA.

EPA (2008). Sodium Ferric Ethylenediaminetetraacetate Biopesticides Registration Action Document. Washington, DC: EPA.

EPA (2015). Metaldehyde; Pesticide Tolerances. Washington, DC: EPA.
FAO (2005). Manejo Integrado de la Babosa del Frijol. Tegucigalpa: FAO.

Galvis, F., and Moreno, L. (2018). Identification of Cryl genes in Bacillus thuringiensis isolates and their toxic effect against Milax gagates, a pest on lettuce (Lactuca sativa). Rev. Chapingo Ser. Hortic. 24, 97-106. doi: 10.5154/r.rchsh.2017.07.025

Gimingham, C. T. (1940). Some recent contributions by English workers to the development of methods of insect control. Ann. Appl. Biol. 27, 161-175. doi: 10.1111/j.1744-7348.1940.tb07486.x

Godeke, J., Wegener, J. K., von Horsten, D., and Hoing, C. (2019). Entwicklung einer Robotik-Lösung zur Schneckenbekämpfung im Ackerbau. Gesunde Pflanz. 71, 73-78. doi: 10.1007/s10343-019-00444-y

Gomes, S. R., Robinson, D. G., Zimmerman, F. J., Obregon, O., and Barr, N. B. (2013). Morphological and molecular analysis of the Andean slugs Colosius confusus, n. sp., a newly recognized pest of cultivated flowers and coffee from Colombia, Ecuador and Peru, and Colosius pulcher (Colosi, 1921) (Gastropoda, Veronicellidae). Malacologia 56, 1-30. doi: 10.4002/040.056.0201

Gregoric, D. E. G., Beltramino, A. A., Vogles, R. E., Cuezzo, M. G., Núnez, V., Gomes, S. R., et al. (2013). First records of four exotic slugs in Argentina. Amer. Malac. Bull. 31, 245-256. doi: 10.4003/006.031.0204

Grisotti, M., and Ávila-Pires, F. D. (2011). Impactos socioeconômicos de uma doença emergente. Cien Saude Colet 16, 647-656. doi: 10.1590/S1413-81232011000200028

Hajian-Forooshani, Z., Vandermeer, J., and Perfecto, I. (2020). Insights from excrement: invasive gastropods shift diet to consume the coffee leaf rust and its mycoparasite. Ecology 101:e02966. doi: 10.1002/ecy.2966

Hausdorf, B. (2001). Macroevolution in progress: competition between semislugs and slugs resulting in ecological displacement and ecological release. Biol. J. Linn. Soc. 74, 387-395. doi: 10.1006/bijl.2001.0591

Hausdorf, B. (2002). Introduced land snails and slugs in Colombia. J. Molluscan Stud. 68, 127-131. doi: 10.1093/mollus/68.2.127

Henderson, I. F. (1968). Laboratory methods for assessing toxicity of contact poisons to slugs. Ann. Appl. Biol. 62:363. doi: 10.1111/j.1744-7348.1968.tb05449.x

Howe, D. K., Ha, A. D., Colton, A., De Ley, I. T., Rae, R. G., Ross, J., et al. (2020). Phylogenetic evidence for the invasion of a commercialized European Phasmarhabditis hermaphrodita lineage into North America and New Zealand. PLoS ONE 15:e0237249. doi: 10.1371/journal.pone.0237249

Kay, P., and Grayson, R. (2014).Using water industry data to assess the metaldehyde pollution problem. Water Environ. J. 28, 410-417. doi: 10.1111/wej.12056

Kozlowski, J., Jaskulska, M., and Kozlowska, M. (2018). Damage to the legume (Fabaceae) and rapeseed (Brassicaceae) plants caused by Arion vulgaris Moquin-Tandon, 1855, A-Rufus (Linnaeus, 1758) and Deroceras reticulatum (O. F. Muller, 1774). Folia Malacol 26, 207-211. doi: 10.12657/folmal.026.021

Kramer, M. H., Greer, G. J., Quinonez, J. F., Padilla, N. R., Hernandez, B., Arana, B. A., et al. (1998). First reported outbreak of abdominal angiostrongyliasis. Clin. Infect. Dis. 26, 365-372. doi: 10.1086/516325

Laitano, A. C., Genro, J. P., Fontoura, R., Branco, S. S. L., Maurer, R. L., Graeff-Teixeira, C., et al. (2001). Report on the occurrence of Angiostrongylus costaricensis in southern Brazil, in a new intermediate host from the genus Sarasinula (Veronicellidae, Gastropoda). Rev. Soc. Bras. Med. Trop. 34, 95-97. doi: 10.1590/S0037-86822001000100015

Landal, M. C. T., Bach, R. P., Gomes, S. R., Botton, M., and Zawadneak, M. A. C. (2019). Terrestrial gastropods as Fragaria $\mathrm{x}$ ananassa pests in southern Brazil: morphological identification. Ciênc. Rural 49, 1-8.

Le Gall, M., and Tooker, J. F. (2017). Developing ecologically based pest management programs for terrestrial molluscs in field and forage crops. J. Pest Sci. 90, 825-838. doi: 10.1007/s10340-017-0858-8

Lydeard, C., Cowie, R. H., Ponder, W. F., Bogan, A. E., Bouchet, P., Clark, S. A., et al. (2004). The global decline of nonmarine mollusks. Bioscience 54, 321-330. doi: 10.1641/0006-3568(2004)054[0321:TGDONM]2.0.CO;2

Maas, B., Karp, D. S., Bumrungsri, S., Darras, K., Gonthier, D., Huang, J. C. C., et al. (2020). Bird and bat predation services in tropical forests and agroforestry landscapes. Biol. Rev. 91, 1081-1101. doi: 10.1111/brv.12211

Martinez, J. W., Bohorquez, S. L., and Acosta, A. (1994). Determinacion taxonomica de cinco grupos de babosas y estudio del ciclo de vida del grupo predominante en un cultivo comercial de alstroemeria de MadridCundinamarca. Agron. Colomb. 11, 53-61. 
Meléndez, G. (2004). "Chapter 2: Slash-and-Mulch System: Fríjol Tapado in Costa Rica," in Green Manure/Cover Crop Systems of Smallholder Farmers, eds M. Eilittä, J. Mureithi, and R. Derpsch (Dordrecht: Springer).

Meyer, W. M., Ostertag, R., and Cowie, R. H. (2013). Influence of terrestrial molluscs on litter decomposition and nutrient release in a Hawaiian Rain Forest. Biotropica 45, 719-727. doi: 10.1111/btp.12057

Mier y Terán Giménez Cacho, M., Giraldo, O. F., Aldasoro, M., Morales, H., Ferguson, B. G., Rosset, P., et al. (2018). Bringing agroecology to scale: key drivers and emblematic cases. Agroecol. Sustain. Food Syst. 42, 637-665. doi: $10.1080 / 21683565.2018 .1443313$

Morales, H., and Perfecto, I. (2000). Traditional knowledge and pest management in the Guatemalan highlands. Agr. Hum. Val. 17, 49-63. doi: 10.1023/A:1007680726231

Moreno Suárez, J. R., Gaviria Gutiárrez, B. M., Navarro Alzate, R., Durán Rivera, B., Vargas Duque, A., Aguirre Correa, P., et al. (2008). Babosas en cultivos del Valle de San Nicolás. Rionegro: Grupo de Investigación de Sanidad Vegetal, Malacología, Universidad Católica de Oriente.

Morii, Y., Ohkubo, Y., and Watanabe, S. (2018). Activity of invasive slug Limax maximus in relation to climate conditions based on citizen's observations and novel regularization based statistical approaches. Sci. Total Environ. 637, 1061-1068. doi: 10.1016/j.scitotenv.2018.04.403

Moura, A. P., de Guimaraes, J. A., Guedes, I. M. R., da Silva, J., and Leal, D. C. P. (2018). Manejo de lesmas e caracóis no contexto da produção integrada de hortaliças folhosas. Brasilia: Embrapa Hortaliças.

Nash, M. A., Thomson, L. J., and Hoffmann, A. A. (2007). Slug control in Australian canola: monitoring, molluscicidal baits and economic thresholds. Pest Manag. Sci. 63, 851-859. doi: 10.1002/ps.1411

Neubert, E., Seddon, M. B., Allen, D. J., Arrébola, J., Backeljau, T., Balashov, I., et al. (2019). European Red List of Terrestrial Molluscs. Cambridge; Brussels: IUCN.

Nicolai, A., and Ansart, A. (2017). Conservation at a slow pace: terrestrial gastropods facing fast-changing climate. Conserv. Physiol. 5, 1-17. doi: 10.1093/conphys/cox007

Oliveira, A. P., Gentile, R., Maldonado, A., Lopes Torres, E. J., and Thiengo, S. C. (2015). Angiostrongylus cantonensis infection in molluscs in the municipality of Sao Goncalo, a metropolitan area of Rio de Janeiro, Brazil: role of the invasive species Achatina fulica in parasite transmission dynamics. Mem. Inst. Oswaldo Cruz 110, 739-744. doi: 10.1590/0074-02760150106

Pereira, H. F., and Gonçalves, L. I. (1949). Caramujos, caracosis e lesmas nocivos e meios de combate. Biol. São Paulo 15, 65-73.

Perichi, G. A. (2014). Identificación de la malacofauna de interés agrícola del municipio Tovar, estado Aragua, Venezuela. Caracas: Universidad Central de Venezuela.

Peters, V. E., Carlo, T. A., Mello, M. A. R., Rice, R. A., Tallamy, D. W., Caudill, S. A., et al. (2016). Using plant-animal interactions to inform tree selection in tree-based agroecosystems for enhanced biodiversity. Bioscience 66, 1046-1056. doi: 10.1093/biosci/biw140

Pieterse, A., Malan, A. P., and Ross, J. L. (2016). Nematodes that associate with terrestrial molluscs as definitive hosts, including Phasmarhabditis hermaphrodita (Rhabditida: Rhabditidae) and its development as a biological molluscicide. J. Helminthol. 91, 517-527. doi: 10.1017/S0022149X16000572

Port, G., and Ester, A. (2002). "Chapter 16: Gastropods as pests in vegetable and ornamental crops in Western Europe," in Molluscs as Crop Pests, 1st Edn., ed G. M. Barker (New York, NY: CABI Publishing).

Posada-Flórez, F., Cárdenas-Murillo, R., Arcila-Pulgarín, J., Gil-Vallejo, F., and Mejía-Mejía, C. G. (2001). Las babosas causantes del anillado del tallo del cafeto. Avances Técnicos CENICAFE 289, 1-8.

Robinson, D. G. (1999). Alien invasions: The effects of the global economy on nonmarine gastropod introductions into the United States. Malacologia $41,413-438$.

Robinson, D. G., and Fields, A. (2010). "The leatherleaf slugs (Family Veronicellidae)," in Regional Workshop Mollusk Pests of Economic Importance (San Antonio de Oriente: Centro Kellog, Escuela Agricola Panamericana Zamorano).

Rodriguez, R., Sandri, A. S. S., Porto, S. M., Osório, J. B., Muller, C. A., Cognato, B. B., et al. (2019). Invasive slug Meghimatium pictum (Stoliczka, 1873) infected by Angiostrongylus costaricensis Morera \& Céspedes, 1971, and the possible risk of human infection associated with grape consumption. J. Helminthol. 93, 775-777. doi: 10.1017/S0022149X18000822
Rooduijn, B., Bongers, F., and van der Wal, H. (2018). Wild native trees in tropical homegardens of Southeast Mexico: Fostered by fragmentation, mediated by management. Agric. Ecosyst. Environ. 254, 149-161. doi: 10.1016/j.agee.2017.10.015

Rueda, A., Caballero, R., Kaminsky, R., and Andrews, K. L. (2002). "Chapter 4: Vaginulidae in Central America, with emphasis on the bean slug Sarasinula plebeia (Fischer)," in Molluscs as Crop Pests, 1st Edn., ed G. M. Barker (New York, NY: CABI Publishing).

Rumi, A., Sánchez, J., and Ferrando, N. (2010). Theba pisana (Müller, 1774) (Gastropoda, Helicidae) and other alien land molluscs species in Argentina. Biol. Invas. 12, 2985-2990. doi: 10.1007/s10530-01 $0-9715-x$

Ryser, S., Rindlisbacher, N., Gruebler, M. U., and Knop, E. (2011). Differential survival rates in a declining and an invasive farmland gastropod species. Agric. Ecosyst. Environ. 144, 302-307. doi: 10.1016/j.agee.2011. 08.005

Sannazzaro, A. M., Oliveira, S. H. F., and Wutke, E. B. (2000). Danos causados por lesmas (Sarasinula plebeia Fischer) em cultivares de feijoeiro (Phaseolus vulgaris L.). Arq. Inst. Biol. 67, 271-274.

Santacruz, A., Toro, M., and Salazar, C. (2011). Slugs control methods (Deroceras sp. Müller) in lettuce and broccoli crops. Agron. Colomb. 29, 241-247.

Schneider, S. (2016). Family Farming in Latin America and the Caribbean: Looking for New Paths of Rural Development and Food Security (No. 137). Brasilia: International Policy Centre for Inclusive Growth.

Schrodl, M. (2014). Opinion Time to say "Bye-bye Pulmonata"? Spixiana $37,161-164$.

Shiels, A. B., Ennis, M. K., and Shiels, L. (2014). Trait-based plant mortality and preference for native versus non-native seedlings by invasive slug and snail herbivores in Hawaii. Biol. Invas. 16, 1929-1940. doi: 10.1007/s10530-013-0636-3

Simone, L. R. L. (2018). Main processes of body modification in gastropods: the limacization. Malacopedia 1, 12-22.

Slotsbo, S. (2014). NOBANIS - Invasive Alien Species Fact Sheet -Arion lusitanicus (or vulgaris). Online Database of the European Network on Invasive Alien Species - NOBANIS. Available online at: www.nobanis.org

Sommer, R. M., and Cowie, R. H. (2020). Invasive traits of veronicellid slugs in the Hawaiian Islands and temperature response suggesting possible range shifts under a changing climate. J. Molluscan Stud. 86, 147-155. doi: 10.1093/mollus/eyz042

South, A. (2012). Terrestrial Slugs: Biology, Ecology and Control. Netherlands: Springer.

Speiser, B., and Kistler, C. (2002). Field tests with a molluscicide containing iron phosphate. Crop Protect. 21, 389-394. doi: 10.1016/S0261-2194(01) 00120-X

Symondson, W. O. C. (1989). Biological control of slugs by carabids. Monogr. Br. Crop Protect. Council 41, 295-300.

Thiengo, S. C. (1995). Presence of mermithid larvae (Nematoda, Mermithidae) in Limax flavus and Sarasinula marginata (Mollusca, Gastropoda) in Brazil. Mem. Inst. Oswaldo Cruz 90, 347-347. doi: 10.1590/S0074-02761995000 300007

Thomé, J.W. (1993). Estado atual da sistemática dos Veronicellidaee (Mollusca; Gastropoda) americanos, com comentários sobre sua importância econômica, ambiental e na saúde. Biociências 1, 61-75.

Thomé, J. W., and Gomes, S. R. (2011). "Síntese do conhecimento sobe as lesmas terrestres, com ênfase na família mais representativa no Brasil," in Tópicos em Malacologia - Ecos do XIX EBRAM, 1st Edn., eds M. A. Fernandez, S. B. Santos, A. D. Pimenta, and S. C. Thiengo (Rio de Janeiro: Sociedade Brasileira de Malacologia).

Valente, R., Robles, M., and del, R., Diaz, J. I. (2020). Gastropods as intermediate hosts of Angiostrongylus spp. in the Americas: bioecological characteristics and geographical distribution. Mem. Inst. Oswaldo Cruz 115, 1-9. doi: 10.1590/0074-027602 00236

Velazquez-Montes de Oca, M. Y., Camacho, A. D., Naranjo-Garcia, E., and Tovar-Soto, A. (2014). Distribución e incidencia de Leidyula moreleti y Sarasinula plebeia (Soleolifera: Veronicellidae), babosas plaga en la región principal productora de vainilla en México. Rev. Mex. Biodivers. 85, 1139-1144. doi: $10.7550 / \mathrm{rmb} .42653$ 
Viviani, V. R. (2001). Fireflies (Coleoptera : Lampyridae) from southeastern Brazil: Habitats, life history, and bioluminescence. Ann. Entomol. Soc. Am. 94, 129-145. doi: 10.1603/0013-8746(2001)094[0129:FCLFSB]2.0.CO;2

Willig, M. R., and Camilo, G. R. (1991). The effect of Hurricane Hugo on six invertebrate species in the Luquillo Experimental Forest of Puerto Rico. Biotropica 23, 455-461. doi: 10.2307/2388266

Wilson, M. J., Glen, D. M., Wiltshire, C. W., and George, S. K. (1994). Mini-plot field experiments using the Rhabditid nematode Phasmarhabditis hermaphrodita for biocontrol of slugs. Biocontrol Sci. Technol. 4, 103-113. doi: 10.1080/095831594093 55318
Conflict of Interest: The authors declare that the research was conducted in the absence of any commercial or financial relationships that could be construed as a potential conflict of interest.

Copyright $\odot 2021$ Ramos, Gomes, Gutierrez, Ramos-Rodriguez and Uzeda. This is an open-access article distributed under the terms of the Creative Commons Attribution License (CC BY). The use, distribution or reproduction in other forums is permitted, provided the original author(s) and the copyright owner(s) are credited and that the original publication in this journal is cited, in accordance with accepted academic practice. No use, distribution or reproduction is permitted which does not comply with these terms. 